\title{
Characterization and in vitro studies on anticancer, antioxidant activity against colon cancer cell line of gold nanoparticles capped with Cassia tora SM leaf extract
}

\author{
Ezra Elumalai Abel • Preetam Raj John Poonga • \\ Shirly George Panicker
}

Received: 27 January 2015/Accepted: 11 February 2015/Published online: 22 February 2015

(C) The Author(s) 2015. This article is published with open access at Springerlink.com

\begin{abstract}
This study was aimed to determine the effectiveness of synthesized gold nanoparticles of an ethnobotanically and medicinally important plant species Cassia tora against colon cancer cells and to find its antibacterial and antioxidant activities. In order to improve the bioavailability of $C$. tora, we synthesized gold nanoparticles through green synthesis, by simple mixing and stirring of $C$. tora leaf powder and tetrachloroauric acid $\left(\mathrm{HAuCl}_{4}\right)$ solution which gave a dispersion of gold nanoparticles conjugate with $C$. tora secondary metabolites (SMs) with characteristic surface plasmon resonance. It was characterized by Fourier transform infrared spectroscopy, zeta sizer, zeta potential and transmission electron microscopy. Antibacterial activity was carried out for gold nanoparticles conjugated with $C$. tora SMs, using well-diffusion method. The MTT assay for cell viability and markers such as catalase, nitric oxide and lipid peroxidation was predictable to confirm the cytotoxicity and antioxidant properties. The treatment of gold nanoparticles conjugated with $C$. tora SMs on Col320 cells showed reduction in the cell viability through MTT assay, and it also significantly suppressed the release of $\mathrm{H}_{2} \mathrm{O}_{2}$, LPO and NO production in a dose-dependent manner. C. tora SMs conjugate gold nanoparticles
\end{abstract}

E. E. Abel $(\varangle) \cdot$ P. R. John Poonga $(\varangle) \cdot$ S. G. Panicker Department of Plant Biology and Biotechnology, PG Biotechnology, Loyola College, Chennai 600 034,

Tamil Nadu, India

e-mail: loyolaezra@gmail.com

P. R. John Poonga

e-mail: preetamraj.jp@gmail.com

S. G. Panicker

Helen Keller Research Center, Loyola College, Chennai,

Tamil Nadu, India showed enhanced bioavailability, antioxidant and anticancer effect against colon cancer cell line (Col320).

Keywords Antibacterial - Anticancer - Antioxidants . FT-IR $\cdot$ AuNps $\cdot$ C. tora SMs

\section{Introduction}

The nature has provided the storehouse of remedies to cure many ailments of mankind. The traditional herbal medicines are still practiced in large part of our country mostly in tribal and rural areas. In many developing countries, large section of population relies on traditional medicinal plants since they contain active constituents that are used in the treatment of many human diseases (Stary and Hans 1998). Cassia tora Linn. Family: Caesalpiniaceae is an annual herb, $30-39 \mathrm{~cm}$ high, growing in India as wasteland rainy season weed. These herbs have been reported for their usefulness in the form of decoctions, infusions and tinctures in traditional system of medicines for treating skin diseases like psoriasis, leprosy and many more (Horvath 1992; Zahra et al. 2000; Cordova et al. 2002; Harrison 2003). C. tora was also reported for the presence of phytochemical such as anthraquinones, carbohydrates, glycosides, cardiac glycosides, amino acid, phytosterols, fixed oils and fats, phenolic compounds, tannins, flavonoids, steroids and saponins (Sathya and Ambikapathy 2012). And with high anthraquinone content, including chrysophanol, physcion and obtusin may aid in cancer prevention (Qi 2011). At present scenario, the pharmaceutical research has focused on the potent activities of $C$. tora, including its anti-aging, anticancer and antioxidant effects (Chen et al. 2014). Hence, the current study was intended to use $C$. tora as a bioreductant and capping agent for the synthesis of

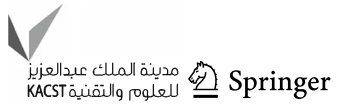


gold nanoparticles as a promising carrier and therapeutic drug for cancer.

The biologically inspired experimental processes for the synthesis of nanoparticles are evolving into an important branch of nanotechnology. Gold nanoparticles have advantages over other metal nanoparticles due to their biocompatibility and non-cytotoxicity. Nanoparticles are nanometers in size. Gold is used internally in human for the last five decades due to their chemical inertness. These are also used in chemotherapy and diagnosis of cancer cell (Cai and Chen 2007). Biological synthesis of nanoparticles appears to be simple, cost-effective, non-toxic and easy to use for controlling size, shape and stability, which is unlike the chemically synthesized nanoparticles (Gurunathan et al. 2014). Gold nanoparticles occur in various size ranges from 2 to $100 \mathrm{~nm}$, but 20-50 nm particles size range shows the most efficient cellular uptake. Specific cell toxicity is shown by $40-50 \mathrm{~nm}$ sized particles. These $40-50 \mathrm{~nm}$ particles diffuse into tumors and can be easily recovered. But the larger particles $80-100 \mathrm{~nm}$ do not diffuse into the tumor and stay near the blood vessels (El-Sayed et al. 2006). These have a great extinction coefficient (Alvarez et al. 1997). Thus, gold nanoparticles have a great contribution in cancer therapy, diagnosis of cancerous cell and importance in the therapy of HIV (Bowman et al. 2008). Colon cancer is the third most common cancer and the third leading cause of cancer death in men and women. In this study, we took colon cancer cell line and treated it with AuNPs-C. tora SMs conjugate to find its anticancer activity.

\section{Materials and methods}

\section{Collection of plant material}

Leaves of $C$. tora were collected from Cuddalore and Poonamallee, Chennai, Tamil Nadu, South India. It was authenticated by a plant taxonomist Preetam Raj JP from the Department of Plant Biology and Biotechnology, Loyola College, Chennai.

Bio-reduction of gold nanoparticles by $C$. tora leaves

Glasswares were rinsed with deionized water before starting the synthesis. $\mathrm{HAuCl}_{4}$ was obtained from SigmaAldrich Chemicals. One gram of leaf powder was boiled in $10 \mathrm{ml}$ of deionized water and subsequently filtered through Whatman No. 1 filter paper. An aliquot of $500 \mu$ was taken and mixed with $99 \mathrm{ml}$ of deionized water to that $1 \mathrm{ml}$ of
$1 \mathrm{mM} \mathrm{HAuCl} 4$ was added. The mixture was kept on magnetic stirrer for $24 \mathrm{~h}$.

Characterization of synthesized AuNPs

\section{UV-Visible spectroscopy studies}

UV-Vis spectroscopy measurements of the $\mathrm{HAuCl}_{4}$ solution and C. tora SMs capped gold colloidal solution were carried out on a UV-Vis spectrophotometer (Model UV2450-Elico). Scanning was done from 200 to $800 \mathrm{~nm}$.

\section{Particle size analysis and zeta potential determination}

The particle size ranges of the nanoparticles were determined using particle size analyzer (ZetasizerNano ZSMalvern), and potential was measured using zeta potential. Particle sizes were calculated based on measuring the timedependent fluctuation of scattering of laser light by the nanoparticles.

\section{FT-IR spectroscopy measurements}

After complete reduction of $\mathrm{HAuCl}_{4}$ ions by $C$. tora $\mathrm{SMs}$, the colloidal gold nanoparticles were centrifuged at $12,000 \mathrm{rpm}$ for $10 \mathrm{~min}$ at room temperature. The gold nanoparticle pellet obtained after centrifugation was resuspended in deionized water and centrifuged again to remove the traces of unbound leaf extract present in the solution prior to FT-IR analysis. FT-IR spectrum was taken to assess the involvement of possible capping by the plant extract (both aqueous and gold nanoparticles). Measurements were carried out on a Perkin-Elmer FT-IR Spectrum One spectrophotometer.

\section{Dark field and HR-TEM measurements}

Dark-field microscopy enables detailed studies of the plasmonic features of noble metal nanoparticles. AuNPsC. tora SMs nominally sized 40-60 were used due to their stability. These particle qualities were diluted in essentially particle-free double-distilled $\mathrm{H}_{2} \mathrm{O}$ and mixed to obtain suitable bimodal particle suspensions (Wagner et al. 2014). Olympus BX51 microscope was used which was illuminated with dark-field condenser. TEM samples of the gold nanoparticles were prepared by placing a drop over carboncoated copper grid and allowing the solvent to evaporate. TEM measurements were performed on a TECHAN Philips model 2400EX instrument operated at an accelerating voltage between 80 and $200 \mathrm{kV}$. 
Antibacterial activity

\section{Test microorganisms}

Bacillus subtilis (MTCC 441), Enterococcus faecalis (ATCC 29212), Staphylococcus aureus (ATCC 25923), Staphylococcus epidermidis (MTCC 3615), Escherichia coli (ATCC 25922) and Proteus vulgaris (MTCC 1771) were used for the experiment.

\section{Well-diffusion assay}

Antimicrobial activity was carried out using well-diffusion method. Petri plates were prepared with $20 \mathrm{ml}$ of sterile Mueller-Hinton agar (MHA) (Hi-Media, Mumbai) for bacteria. The test cultures were swabbed on the top of the solidified media and allowed to dry for $10 \mathrm{~min}$. The aqueous extract of $C$. tora leaves and synthesized $C$. toraAuNPs (100 and $150 \mu \mathrm{l})$ were loaded and left for $30 \mathrm{~min}$ at room temperature for compound diffusion. $\mathrm{HAuCl}_{4} 3 \mathrm{H}_{2} \mathrm{O}$ was used as control. The plates were incubated for $24 \mathrm{~h}$ at $37^{\circ} \mathrm{C}$ for bacteria to grow, and the zone of inhibition was measured in millimeters $(\mathrm{mm})$. The experiment was repeated twice.

\section{Anticancer activity}

Col320 cell lines were obtained from National Centre for Cell Sciences, Pune, India, and grown on Dulbecco's modified essential medium supplemented with $10 \%$ (v/v) fetal calf serum, penicillin $(100 \mu / \mathrm{ml})$ and streptomycin $(100 \mu \mathrm{g} / \mathrm{ml})$. Cells were seeded in 24 well plates at a concentration of $3 \times 10^{4}$ cells $/ \mathrm{ml}$ of DMEM/well and incubated for $48 \mathrm{~h}$ at $37^{\circ} \mathrm{C}$ under $5 \% \mathrm{CO}_{2}$ to attain confluence. The cells were then treated with various concentrations $(25,50$ and $75 \mu \mathrm{g} / \mathrm{ml})$. Then, the cells were incubated for $24 \mathrm{~h}$, and cell supernatants $(100 \mu \mathrm{l})$ were analyzed for leakage of catalase levels, using commercial spectrophotometric kits. The cells were used to analyze viability, NO production and lipid peroxidation. The experiments were carried out in triplicates in each group.

Estimation of cell viability-MTT assay

The MTT assay is a colorimetric assay for measuring the activity of cellular enzymes that reduce the tetrazolium dye, MTT, to its insoluble formazan, giving a purple color. MTT (3-4,5-dimethylthiazol-2-yl)-2,5-diphenyltetrazolium bromide, a yellow tetrazole) is reduced to purple formazan in living cells (Gerlier and Thomasset 1986; Mossman 1983). A solubilization solution (usually dimethyl sulfoxide, an acidified ethanol solution or a solution of the detergent sodium dodecyl sulfate in diluted hydrochloric acid) is added to dissolve the insoluble purple formazan product into a colored solution. The absorbance of this colored solution can be quantified by measuring at a certain wavelength (usually between 500 and $600 \mathrm{~nm}$ ) by a spectrophotometer. Cell proliferation was measured using MTT assay. After $24 \mathrm{~h}$ of treatment, $20 \mu \mathrm{l}$ of MTT solution ( $5 \mathrm{mg}$ MTT in $1 \mathrm{ml}$ PBS) was added per well and incubated at $37{ }^{\circ} \mathrm{C}$ for $4 \mathrm{~h}$ in $5 \%$ $\mathrm{CO}_{2}$ atmosphere. Then, the medium was removed and washed with PBS; $200 \mu \mathrm{l}$ of DMSO was added to each well. The intensity of the colored product was measured using an ELISA microplate reader at $570 / 620 \mathrm{~nm}$. The results were expressed as the percent optical density of treated cells to that of the control cell.

\section{Estimation of catalase}

To $0.1 \mathrm{ml}$ of sample, $1 \mathrm{ml}$ of phosphate buffer and $1 \mathrm{ml}$ of hydrogen peroxide was added, and the timer was started. The reaction was arrested by the addition of $2 \mathrm{ml}$ dichromate-acetic acid reagent. Standard hydrogen peroxide $(20 \mu \mathrm{M})$ was taken and treated similarly. The tubes were heated in the boiling water bath for $10 \mathrm{~min}$. The green color developed was read at $570 \mathrm{~nm}$ using spectrophotometer.

\section{Assay for NO production}

Nitric oxide (NO) plays an important role in neurotransmission, vascular regulation, immune response and apoptosis. NO is rapidly oxidized to nitrite and nitrate which are used to quantitate NO production. NO is a reactive radical that plays an important role in many key physiological functions. NO, an oxidation product of arginine by nitric oxide synthase (NOS), is involved in host defense and development, activation of regulatory proteins and direct covalent interaction with functional biomolecules. Simple, direct and non-radioactive procedures for measuring NOS are becoming popular in research and drug discovery. Nitric oxide synthase assay involves two steps: a NOS reaction step during which $\mathrm{NO}$ is produced followed by an NO detection step. Since the NO generated by NOS is rapidly oxidized to nitrite and nitrate, the NO production is measured following reduction of nitrate to nitrite using an improved Griess method. The procedure is reduced to as short as $40 \mathrm{~min}$. This assay determines nitric oxide based on the enzymatic conversion of nitrate to nitrite by nitrate reductase. The reaction is followed by a colorimetric detection of nitrite as an azo dye product of the Griess reaction. The Griess reaction is based on the two-step diazotization reaction in which acidified $\mathrm{NO}_{2}$ produces a 
nitro-sating agent which reacts with sulfanilic acid to produce the diazonium ion. This ion is then coupled to $\mathrm{N}$-(1-naphthyl) ethylenediamine to form the chromophoric azo derivative, which absorbs light at $540 \mathrm{~nm}$. After $24 \mathrm{~h}$ of incubation, the level of NO production was monitored by measuring the nitrite concentration in the supernatant of cultured medium using the Griess reagent.

\section{Estimation of lipoperoxides}

Quantification of lipid peroxidation is essential to assess oxidative stress in pathophysiological processes. Lipid peroxidation forms malondialdehyde (MDA) and 4-hydroxynonenal (4-HNE), as natural by-products. Measuring the end products of lipid peroxidation is one of the most widely accepted assays for oxidative damage. Lipid peroxidation assay provides a convenient tool for sensitive detection of the MDA in a variety of samples. The MDA in the sample is reacted with thiobarbituric acid (TBA) to generate the MDA-TBA adduct. The MDA-TBA adduct can be easily quantified colorimetrically $(\lambda=532 \mathrm{~nm})$ or fluorometrically $(\mathrm{Ex} / \mathrm{Em}=532 / 553 \mathrm{~nm})$. This assay detects MDA levels as low as $1 \mathrm{nmol} /$ well colorimetrically and $0.1 \mathrm{nmol} /$ well fluorometrically. After treatment, the cells were trypsinized, suspended in $0.5 \mathrm{ml}$ of PBS and sonicated for $10 \mathrm{~s}$. To this, $0.5 \mathrm{ml}$ of TCA-TBA reagent was added and heated to $100{ }^{\circ} \mathrm{C}$ for an hour and centrifuged. The extent of lipid peroxidation was quantified by estimating the levels of malondialdehyde. The absorbance was measured at $535 \mathrm{~nm}$, and the results were expressed as nmol/mg protein (Wu and Cederbaum 2008).

\section{Results and discussion}

Characterization of synthesized AuNPs

\section{Plasmon resonance}

It is a useful technique to study the optical and electrical properties of the materials based on Beer-Lambert law which governs the absorption of light by molecules. Upon mixing the $\mathrm{HAuCl}_{4}$ solution and C. tora leaf powder in deionized water, there was no significant change in the UV-Vis spectra (at $0 \mathrm{~h}$ ), only the characteristic signature of $C$. tora leaf around $250 \mathrm{~nm}$ was seen, which we speculate may be due to complexation of $\mathrm{Au}^{3+}$ with $C$. tora leaf powder. Spectrophotometric absorption measurements in the wavelength ranges of 400-450 $\mathrm{nm}$ (Huang et al. 2007) and 500-550 nm (Shankar et al. 2004) are used in characterizing the silver and gold nanoparticles, respectively. As a function of time, we observed an emerging peak around $538 \pm 2.82 \mathrm{~nm}$ (Fig. 1a), which was in the expected range. At this point of time, the color of the reaction mixture changed from gold to light purple color which is an indication of the formation of AuNPs. The formation of gold nanoparticles was visually confirmed by the color change (Fig. 1b). Such a color transition is often indicative of changes in the metal oxidation state (Fujiwara et al. 2007). The increase in the background may be due to the aggregation happened in the synthesized non-purified AuNPs-C. tora leaf conjugates (Choudhury et al. 2013). It is well known that the particles aggregate the background scattering. As one can observe the NPs formation after $2 \mathrm{~h}$,
Fig. 1 UV-visible

spectroscopy showing spectrum the of gold chloride solution at initial time and colloidal solution of AuNPs bioreduction of C. tora SMs after $24 \mathrm{~h}$. Inset optical photograph of colloidal solution

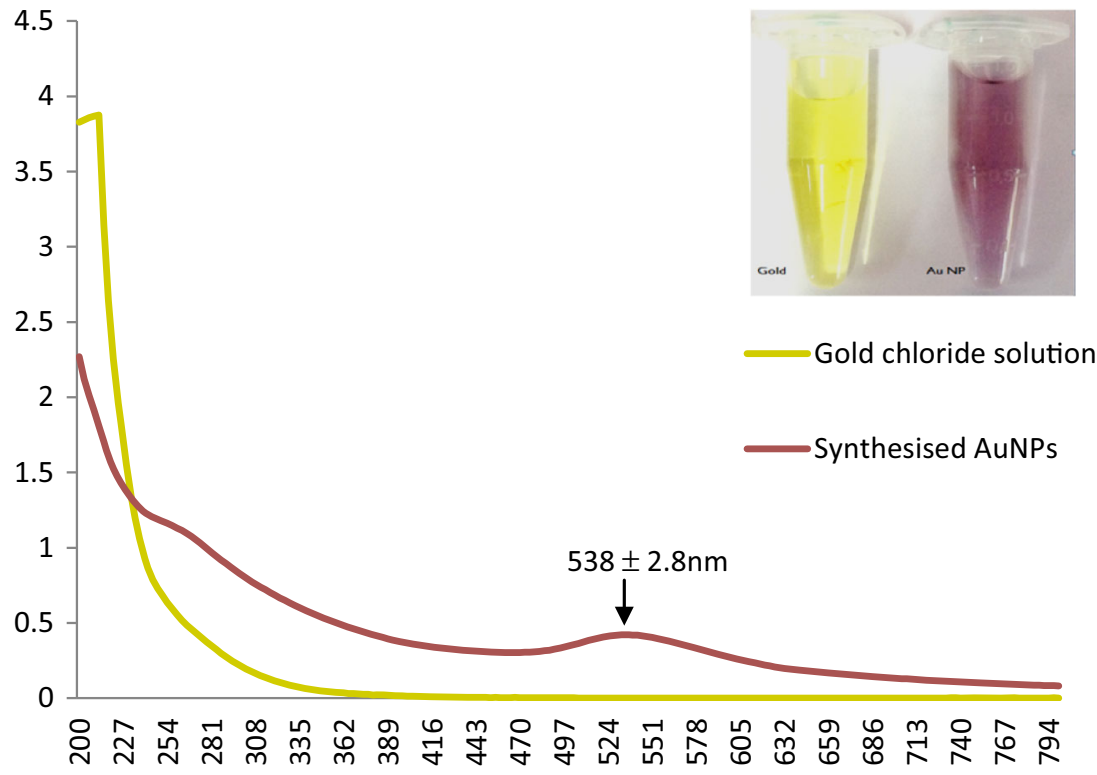


(a)

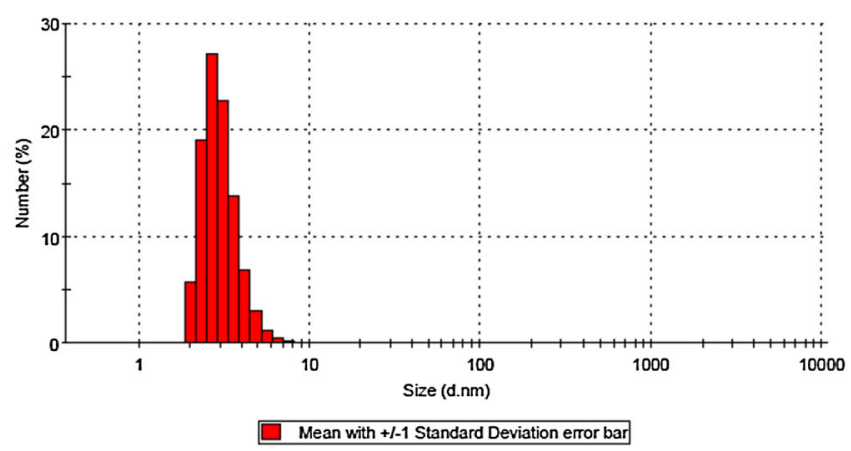

(b) Zeta Potential Distribution

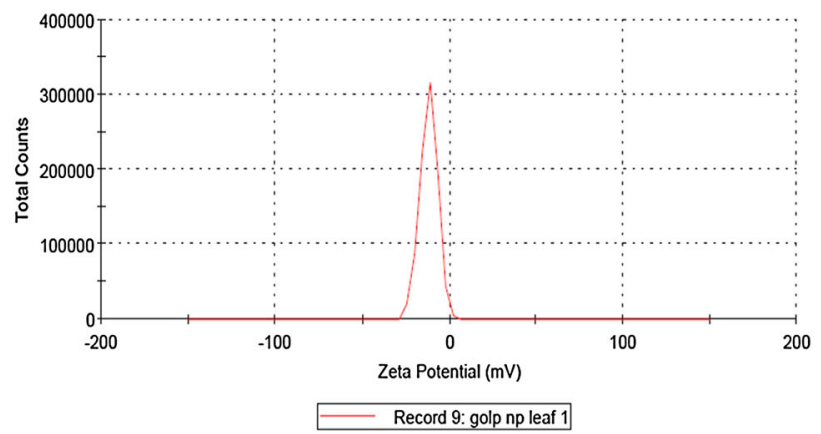

Fig. 2 a Particle size measurement b zeta potential measurement of AuNPs conjugated C. tora SMs

however, clear light purple color was observed by $24 \mathrm{~h}$, indicating the completion of the reaction. More studies are required to prove the intermediates involved in the reaction. Following the UV-Vis spectroscopic study, we carried out FT-IR study to elucidate the possible structural modification in the $C$. tora leaf molecule, followed by TEM imaging, and zeta potential measurements were done to find the size and charge present on the slip plane of AuNPs.

\section{Zeta sizer and potential}

Zeta potential is the key parameter that controls electrostatic interactions in particle dispersions (Kaszuba et al. 2010). The zeta sizer and potential of AuNPs-C. tora conjugate were $41 \mathrm{~nm}$ and $-12.5 \mathrm{mV}$ (Fig. 2a, b). The negative potential is considered as an incipient stability for colloids (Ostolska and Wisniewska 2014). The AuNPs-C. tora conjugate colloidal solution was found to be stable for 3 month under refrigeration.

\section{$F T-I R$}

The qualitative aspects of infrared spectroscopy are one of the most powerful attributes of this diverse versatile analytical technique (Coates 2000). It is useful for characterizing the surface chemistry (Chithrani et al. 2006). We carried out FT-IR measurements in order to decipher the structural modifications occurred in $C$. tora leaf upon the formation of AuNPs conjugate. Conversely, one may be able to identify indirectly which moiety of $C$. tora leaf is bound to the AuNPs. IR spectroscopy, a vibrational spectroscopic technique, is known for elucidating the finger print of chemical compounds. We observed conspicuous peaks around 3464.15, 2926.01, 2395.59, 2011.76, $1622.13,993.34,844.82$ and a peak around $561.29 \mathrm{~cm}^{-1}$. The peaks around $3400 \mathrm{~cm}^{-1}$ are likely due to the alcohol $\mathrm{OH}$ stretch are usually a broad and strong absorption near
3400 and presence of residual water molecules in synthesized AuNPs. The peaks around $2750-3000 \mathrm{~cm}^{-1}$ are likely to originate from carbonyl $\mathrm{C}=\mathrm{O}$ group which is present in the synthesized AuNPs. The peaks around $2300-2100 \mathrm{~cm}^{-1}$ indicate $\mathrm{C} \equiv \mathrm{X}$ stretch region, the peaks around $1600-1750 \mathrm{~cm}^{-1}$ are likely due to the amide present in the synthesized AuNPs, and the peaks around $1500-400 \mathrm{~cm}^{-1}$ fingerprint region arise from complex deformations of the molecule. They may be characteristic of molecular symmetry, or combination bands arising from multiple bonds deforming simultaneously or the presence of peaklets at the lower wave numbers following it also could likely suggest the presence of aromatic $\mathrm{C}=\mathrm{C}$, which is present in synthesized AuNPs, also the disappearance of the peaklets at the lower wave number region after the formation of AuNPs suggests the possible structural change. Hence, peak around $1620 \mathrm{~cm}^{-1}$ is likely to be aliphatic (alkene) $\mathrm{C}=\mathrm{C}$ also, whose absorption is converged with aromatic and amide absorption bands (Fig. 3a, b). Another potential structure is sharp, medium peak around 1400 , and it signifies aromatic $\mathrm{C}=\mathrm{C}$ group, but it shifted in synthesized AuNPs.

\section{Dark field and HR-TEM}

Dark-field microscopy is a widely unknown method to measure the particle size distribution of diffusing nanoparticles by particle tracking (Fig. 4a). TEM is used for morphological characterization at the manometer to micrometer scale. TEM measurements divulged that the resultant product after $24 \mathrm{~h}$ was comprised of nearly spherical AuNPs with 57 nm (Fig. 4b).

Antibacterial activity of synthesized AuNPs and aqueous $C$. tora leaf extract

The $C$. tora leaf may serve as a source of natural bactericidal agents to be used in medicinal systems (Koffi-Nevry 
Fig. 3 Fourier transform infrared (FT-IR) absorption spectra (a) C. tora aqueous extract spectra, $(b)$ AuNPs synthesized by bioreduction of C. tora SMs spectra

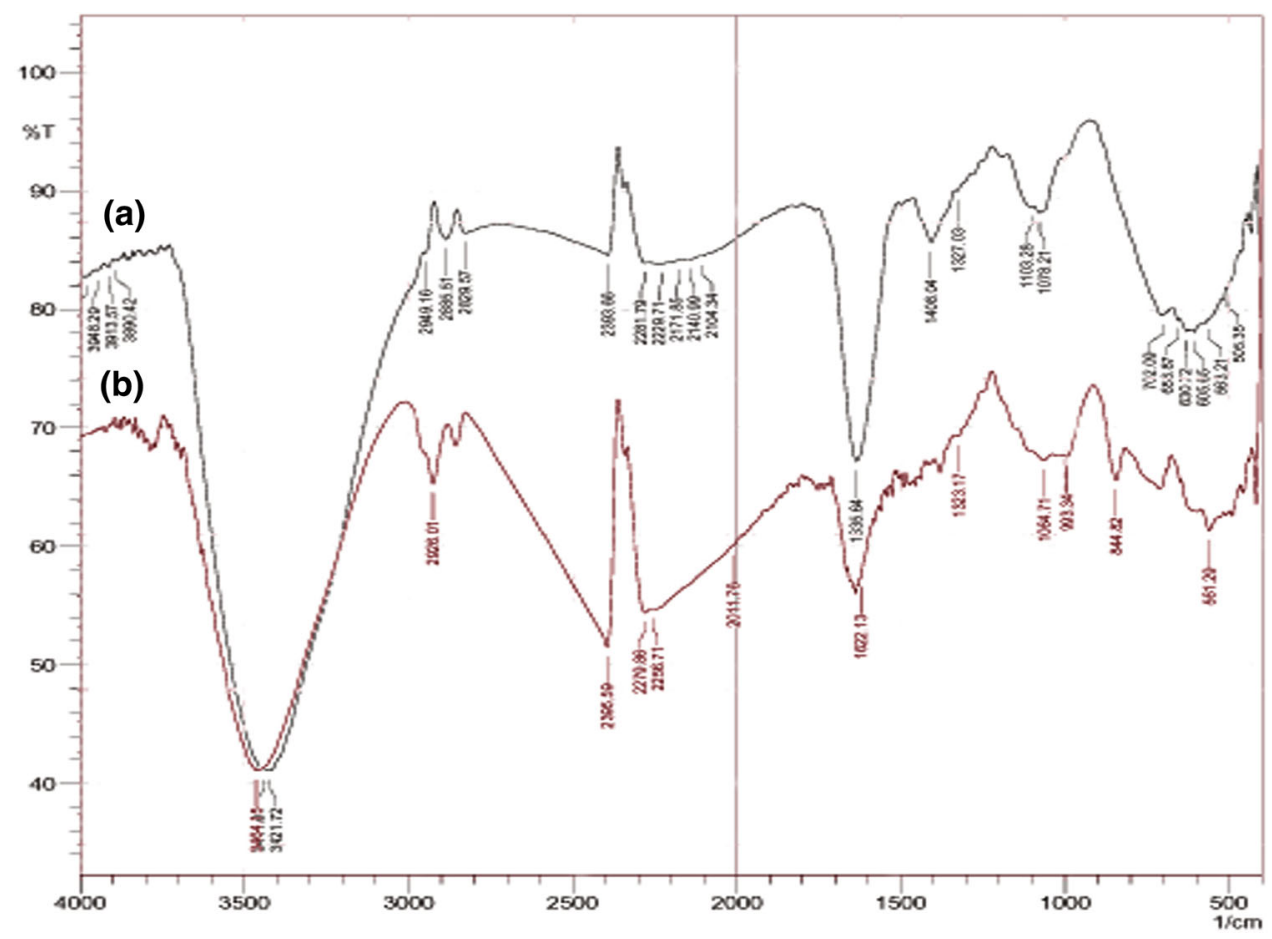

Fig. 4 a Gold colloidal particles under dark-field microscopy $(\times 40)$, b HR-TEM image of synthesized AuNPs conjugated with $C$. tora SMs (Scale bar $-1 \mu \mathrm{m})$
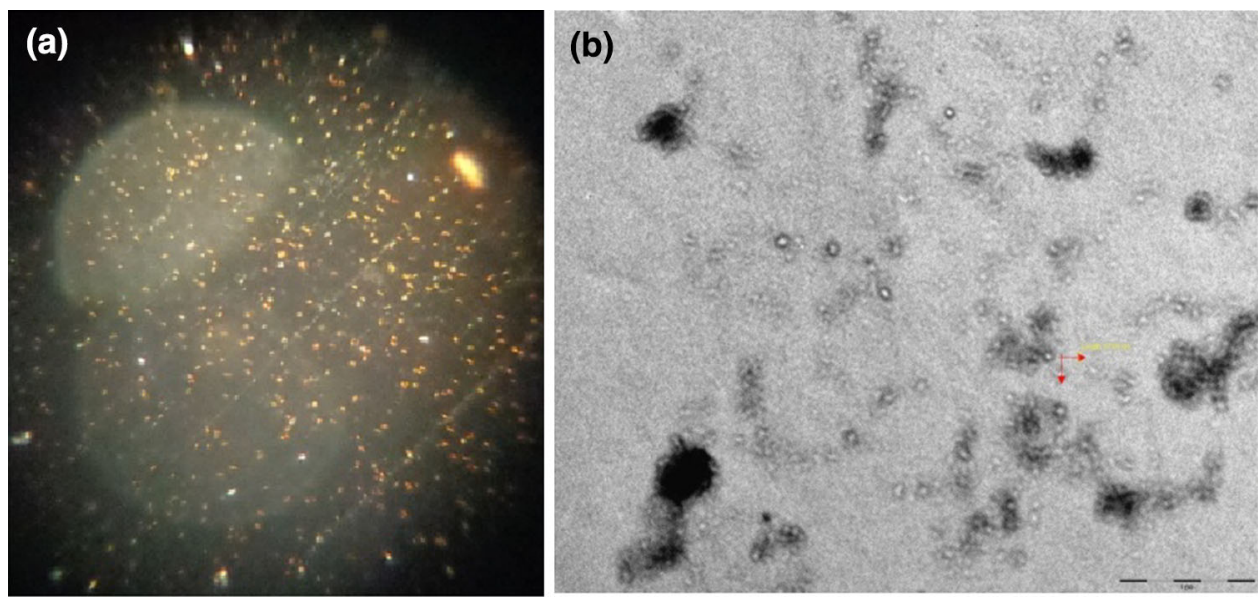

et al. 2012). This study was designed to assess the antibacterial activity of synthesized AuNPs and aqueous C. tora leaf extract against gram-positive and gram-negative bacteria. The green synthesized AuNPs and aqueous C. tora leaf extract showed no inhibition against the grampositive bacteria and gram-negative bacteria.

\section{Anticancer activity}

We intended to use AuNPs capped with $C$. tora leaf extract on cancer cells to observe the enhanced bioavailability and anticancer activity of $C$. tora focusing on colon cancer cell line. Col320 is widely used due to its relatively high steady state functioning of the free radical production and antioxidant defenses; therefore, variations of responses at different conditions are more easily detected.

\section{Estimation of cell viability}

The anticancer activity of the extract was confirmed by MTT assay. The measurement of cell viability plays a fundamental role in all forms of cell culture (Stoddart 2011). Promoting appropriate cell life and death is a key part of cell culture. When cells are put into contact with a SM, their viability may be affected. Some materials are cytotoxic, i.e., deadly to cells. In the present study, the treatment of Col320 cell line with the AuNPs capped with C. tora leaf extract suppressed the cell viability of 

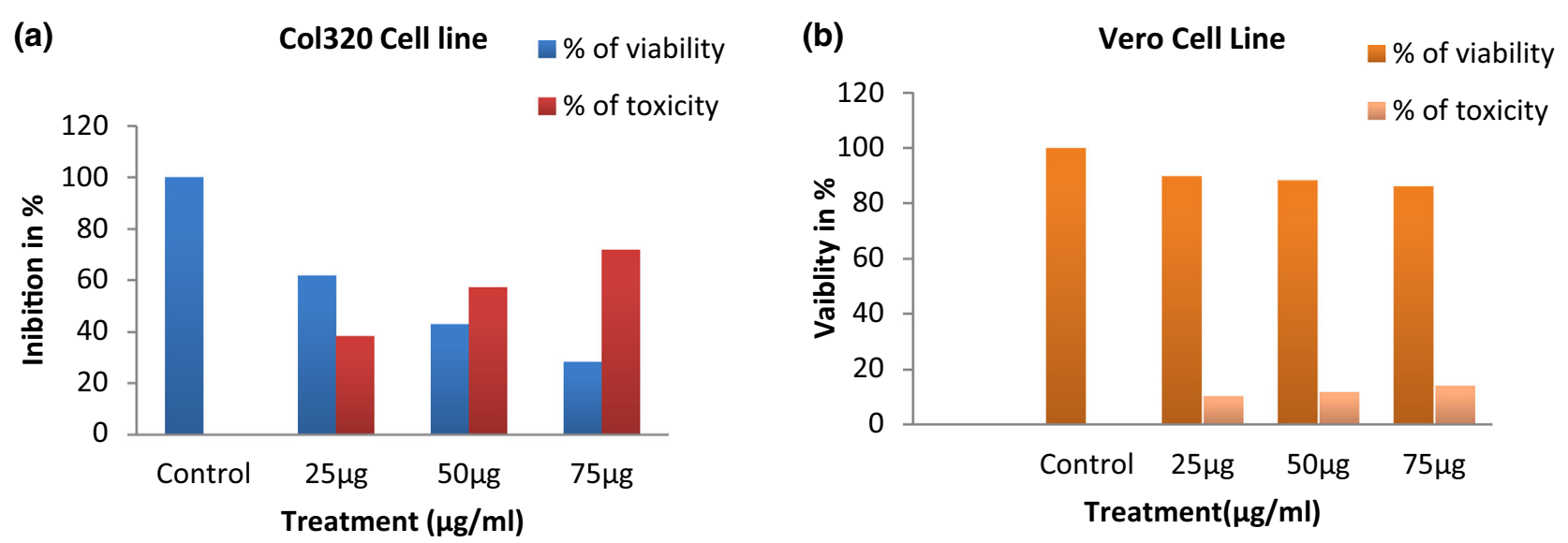

Fig. 5 Graph showing the effect of AuNPs conjugate C. tora on a colon cancer (Col320) and b cell line and Vero cell lines
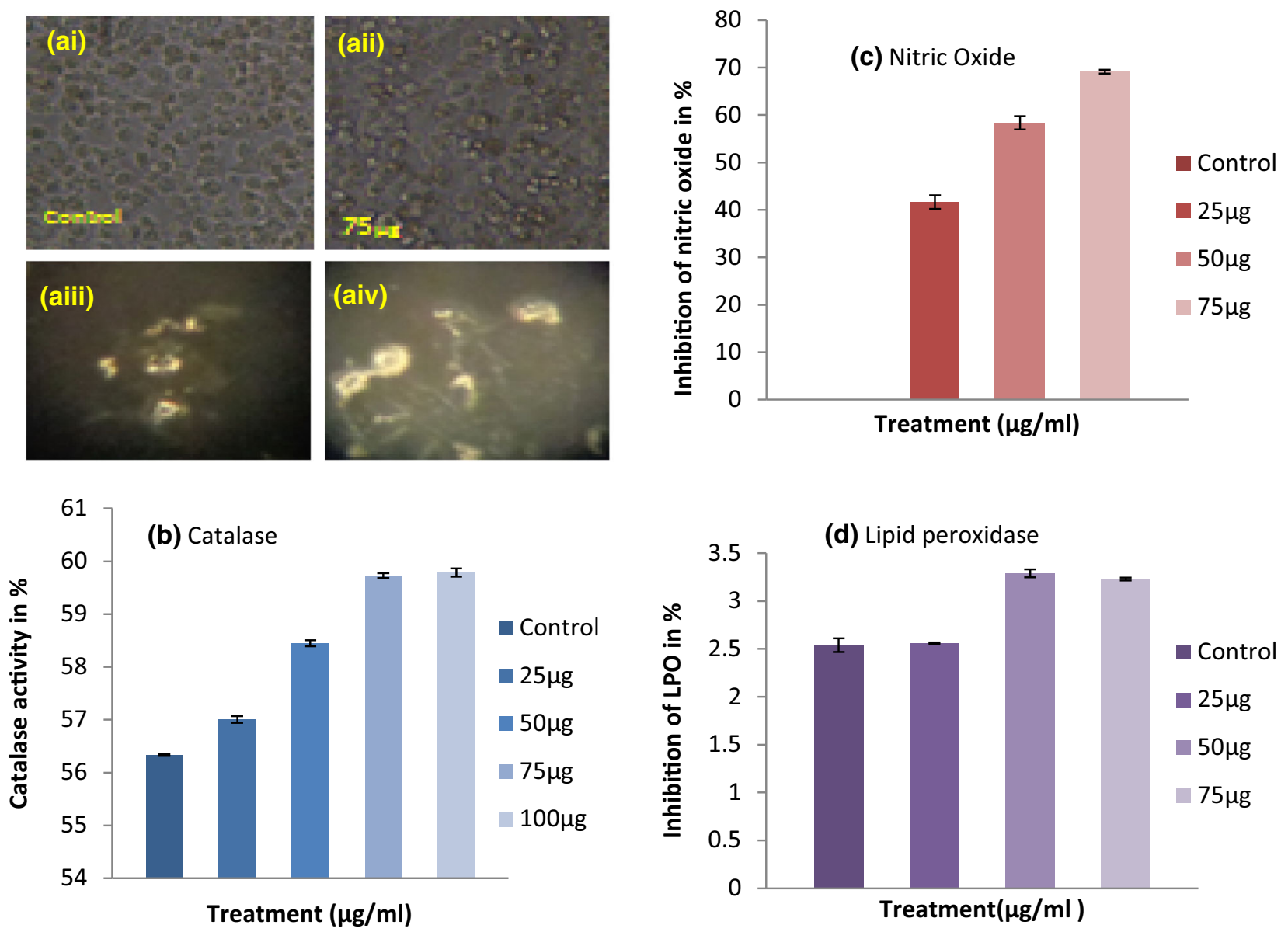

Fig. 6 a Col320 cell lines after $24 \mathrm{~h}$ of incubation ai control, aii AuNPs-C. tora conjugate $75 \mu \mathrm{g}$, aiii dark-field image showing nanoparticles in the Col320 apoptosis cells $\times 10$ and aiv dark-field image at $\times 40$, b catalase activity, $\mathbf{c}$ nitric oxide inhibition and dipid peroxidase activity

cancerous cell up to $(71.2 \%)$ at $(75 \mu \mathrm{g})$ concentrations when compared to the untreated cells (Fig. 5a). Cell morphological changes such as cell shrinkage, loss of surface contact and blebbing were observed in treated cancer cells Col320 cell lines after $24 \mathrm{~h}$ of incubation [Fig. 6a(i, ii)].
Cells were also observed in dark-field microscope [Fig. 6a(iii, iv)]. And we also checked the toxicity of the AuNPs capped $C$. tora leaf extract on normal cell line (Vero), and it is found that our sample does not affect the viability of normal cell (Fig. 5b). Hence, our results 
confirm that the $C$. tora leaf extract conjugated with AuNPs shows higher activity and can be used to enhance activity of colon cancer.

\section{Catalase assay}

To confirm the anticancer activity further, catalase was carried out; catalase is a ubiquitous antioxidant enzyme that degrades hydrogen peroxide into water and oxygen (Loewen et al. 1985), and $\mathrm{H}_{2} \mathrm{O}_{2}$ is very dangerous to the cells and tissues. In our study, when the concentration of the AuNPs capped C. tora leaf extract increased, it showed gradual increase in catalase enzyme, and when enzyme increases, it breaks $\mathrm{H}_{2} \mathrm{O}_{2}$ present in the cancerous cells, and hence, $\mathrm{H}_{2} \mathrm{O}_{2}$ is reduced into non-toxic molecules like water and oxygen (Fig. 6b).

\section{Assay for NO production}

Production of NO molecules is an important cytotoxic function that macrophages use to resolve infection by several obligate intracellular protozoan and bacterial parasites (De Groote and Fang 1995). The inducible form of the NO synthase enzyme (iNOS) produces large amounts of reactive nitrogen molecules by oxidizing the terminal guanidino nitrogen of L-arginine (Dong et al. 1995; Park et al. 1996). Since reactive nitrogen molecules can damage host tissues as well as the invading microbe (Park et al. 1996), nitric oxide at appropriate levels is involved in normal function of organs, whereas uncontrolled release can cause destruction of target tissue during inflammation and septic shock (Saravanan et al. 2012). The treatment with AuNPs-C. tora leaf conjugates $(75 \mu \mathrm{g})$ significantly reduced the release of NO $(69.12 \mu \mathrm{M})$ (Fig. 6c). Low level of NO is important in protecting organs; hence, our sample is capable for reducing NO in the cells and helps in protecting the cells.

\section{Estimation of lipoperoxide}

The major reactive aldehyde resulting from the peroxidation of biological membranes is malondialdehyde (MDA; Vaca et al. 1988). It is used as an indicator of tissue damage by a series of chain reactions (Ohkawa et al. 1979). Malondialdehyde, being a major breakdown product of lipid peroxides, is a useful index of lipid peroxidation (Saravanan et al. 2013). The treatment with AuNPs-C. tora leaf conjugates reduced the release of LPO (3.23). Thus, the study confirmed the anticancer property of AuNPs-C. tora through modulating the free radicals release and also established anti-inflammatory potential (Fig. 6d).

\section{Conclusion}

Aqueous extract of $C$. tora lacks in bioavailability and permeability, mainly due to its poor solubility of extract in water. To improve the bioavailability of $C$. tora, it is conjugated to the surface of metal nanoparticles. In the present study, we report the binding of $C$. tora to the surface of AuNPs. The nanoparticles were characterized by zeta sizer, TEM and FT-IR. We found that $C$. tora acts both as a reducing and capping agent, stabilizing the gold solution. The synthesized AuNPs-C. tora SMs conjugate showed enhanced bioavailability, antioxidant and anticancer effect against colon cancer cell line (Col320). To the best of our knowledge, this is the first report to describe the synthesis of biocompatible and soluble AuNPs with an average size of $41 \mathrm{~nm}$ using $C$. tora. Therefore, this study could provide valuable insight in using AuNPs capped $C$. tora leaf extract as a potential anticancer agent. Further, various parts of this medicinal plant could be explored using nanotechnology for assessing its therapeutic potential.

Open Access This article is distributed under the terms of the Creative Commons Attribution License which permits any use, distribution, and reproduction in any medium, provided the original author(s) and the source are credited.

\section{References}

Alvarez MM, Khoury JT, Schaaff TG, Shafigullin MN, Vezmar I, Whetten RL (1997) Optical absorption spectra of Nanocrystal gold molecules. Phys Chem B 101:3706-3712. doi:10.1021/ jp962922n

Bowman M, Ballard TE, Ackerson CJ, Feldheim DL, Margolis DM, Melander C (2008) Inhibition of HIV fusion with multivalent gold nanoparticles. J Am Chem Soc 130:6896-6897. doi:10. $1021 / \mathrm{ja} 710321 \mathrm{~g}$

Cai W, Chen X (2007) Nanoplatforms for targeted molecular imaging in living subjects. Small 3:1840-1854. doi:10.1002/smll. 200700351

Chen S, Li G, Zhu K, Sun P, Wang R, Zhao X (2014) Antitumor activities of Juemingzi (Cassia tora L.) on Balb/c sarcoma 180-injected mice. Oncol Lett 7(1):250-254

Chithrani BD, Ghazani AA, Chan WCW (2006) Determining the size and shape dependence of gold nanoparticle uptake into mammalian cells. Nano Lett 6:662. doi:10.1021/n1052396o

Choudhury D, Xavier PL, Chaudhari K, John R, Dasgupta AK, Pradeep T, Chakrabarti G (2013) Unprecedented inhibition of tubulin polymerization directed by gold nanoparticles inducing cell cycle arrest and apoptosis. Nanoscale 5:4476-4489. doi:10. 1039/C3NR33891F

Coates J (2000) Interpretation of infrared spectra: a practical approach. In: Meyers RA (ed) Encyclopedia of analytical chemistry. Wiley, Chichester, pp 10815-10837

Cordova CA, Siqueira IR, Netto CA, Yunes RA, Volpato AM, CechinelFilho V, Curi-Pedrosa R, Creszynski-Pasa TB (2002) Protective properties of butanolic extract of the Calendula officinalis L. (marigold) against lipid peroxidation of rat liver 
microsomes and action as free radical scavenger. Redox Rep 7:95-102. doi:10.1179/135100002125000325

De Groote MA, Fang FC (1995) NO inhibitions: antimicrobial properties of nitric oxide. Clin Infect Dis 21(Suppl 2):S162S165. doi:10.1093/clinids/21.Supplement_2.S162

Dong Z, Yang X, Xie K, Juang S-H, Llansa N, Fidler IJ (1995) Activation of inducible nitric oxide synthase gene in murine macrophages requires protein phosphatases 1 and $2 \mathrm{~A}$ activities. J Leukoc Biol 58:725-32. http://www.jleukbio.org/content/58/6/ 725.full.pdf + html

El-Sayed I, Huangand X, El-Say AM (2006) Selective laser photothermal therapy of epithelial carcinoma using anti-EGFR antibody conjugated gold nanoparticles. Cancer Lett 2:129-135. doi:10.1016/j.canlet.2005.07.035

Fujiwara K, Ramesh A, Makia T, Hasegawaa H, Ueda K (2007) Adsorption of platinum (IV), palladium (II) and gold (III) from aqueous solutions onto L-lysine modified cross linked chitosan resin. J Hazard Mater 146:39-50. doi:10.1016/j.jhazmat.2006. 11.049

Gerlier D, Thomasset N (1986) Use of MTT colorimetric assay to measure cell activation. J Immunol Methods 94:57-63. doi:10. 1016/0022-1759(86)90215-2

Gurunathan S, Han J, Park JH, Kim JH (2014) A green chemistry approach for synthesizing biocompatible gold nanoparticles. Nanoscale Res Lett 9:248. doi:10.1186/1556-276X-9-248

Harrison D (2003) Natural therapeutic composition for the treatment of wounds and sores. CIPO Patent 2392544

Horvath F (1992) Therapeutical compositions against psoriasis. US Patent 5165932

Huang J, Li Q, Sun D, Lu Y, Su Y, Yang X, Wang H, Wang Y, Shao W, He N, Hong J, Chen C (2007) Biosynthesis of silver and gold nanoparticles by novel sundried Cinnamomum camphora leaf. Nanotechnology 18(10):105104-105115. doi:10.1088/09574484/18/10/105104

Kaszuba M, Corbett J, Watson FM, Jones A (2010) High-concentration zeta potential measurements using light-scattering techniques. Philos Trans A Math Phys Eng Sci 368(1927):4439-4451. doi:10.1098/rsta.2010.0175

Koffi-Nevry R, Kouassi KC, Nanga ZY, Koussémon M, Loukou GY (2012) Antibacterial activity of two bell pepper extracts: Capsicum annuum L. and Capsicum frutescens. Int J Food Prop 15(5):961-971. doi:10.1080/10942912.2010.509896

Loewen PC, Switala J, Triggs-Raine BL (1985) Catalases HPI and HPII in Escherichia coli are induced independently. Arch Biochem Biophys 243:144-149. doi:10.1016/00039861(85)90782-9

Mossman T (1983) Rapid colorimetric assay for cellular growth and survival: application to proliferation and cytotoxicity assays. J Immunol Methods 65:55-63. doi:10.1016/00221759(83)90303-4
Ohkawa H, Ohishi N, Yagi K (1979) Assay for lipid peroxidation in animal tissues by thiobarbituric acid reaction. Ann Biochem 95:351-358

Ostolska I, Wiśniewska M (2014) Application of the zeta potential measurements to explanation of colloidal $\mathrm{Cr}_{2} \mathrm{O}_{3}$ stability mechanism in the presence of the ionic polyamino acids. Colloid Polym Sci 292(10):2453-2464. doi:10.1007/s00396-014-3276-y

Park YC, Jun CD, Kang HS, Kim HD, Kim HM, Chung HT (1996) Role of intracellular calcium as a priming signal for the induction of nitric oxide synthesis in murine peritoneal macrophages. Immunology 87:296-302. doi:10.1046/j.13652567.1996.456544.x

Qi GF (2011) Cassia analysis of lipid-lowering active ingredients. Guang Ming Zhong Yi 26:1569-1570

Saravanan S, Babu NP, Pandikumar P, Raj MK, Paulraj MG, Ignacimuthu S (2012) Immunomodulatory potential of Enicostema axillare (Lam.) A. Raynal, a traditional medicinal plant. J Ethnopharmacol 140:239-246. doi:10.1016/j.jep.2012.01.010

Saravanan S, Pandikumar P, Pazhanivel N, Gabriel Paulraj M, Ignacimuthu S (2013) Hepatoprotective role of Abelmoschus esculentus (Linn.) Moench on carbon tetrachloride induced liver injury. Toxicol Mech Methods 23(7):528-536. doi:10.3109/ 15376516.2013.796032

Sathya A, Ambikapathy V (2012) Studies on the phytochemistry, antibacterial activity and green synthesis of nanoparticles using Cassia tora L. against amphicillin resistant bacteria. Asian $\mathbf{J}$ Plant Sci Res 2(4):486-489. http://pelagiaresearchlibrary.com/ asian-journal-of-plant-science/vol2-iss4/AJPSR-2012-2-4-486489.pdf

Shankar SS, Rai A, Ankamwar B, Singh A, Ahmad A, Sastry M (2004) Biological synthesis of triangular gold nanoprisms. Nat Mater 3:482-488. doi:10.1038/nmat1152

Stary F, Hans S (1998) The National guides to medical herbs and plants. Tiger Books Int. Plc, UK

Stoddart MJ (2011) Cell viability assays: introduction. Methods Mol Biol 740:1-6. doi:10.1007/978-1-61779-108-6_1

Vaca CE, Wilhelm J, Harms-Ringdahl M (1988) Interaction of lipid peroxidation products with DNA: a review. Mutat Res 195:137-149. doi:10.1016/0165-1110(88)90022-X

Wagner T, Lipinski HG, Wiemann M (2014) Dark field nanoparticle tracking analysis for size characterization of plasmonic and nonplasmonic particles. J Nanopart Res. doi:10.1007/s11051-0142419-x

Wu D, Cederbaum A (2008) Cytochrome P4502E1 sensitizes to tumor necrosis factor alpha-induced liver injury through activation of mitogen-activated protein kinases in mice. Hepatology 47(3):1005-1017. doi:10.1002/hep.22087 